УДК 621.384 .4

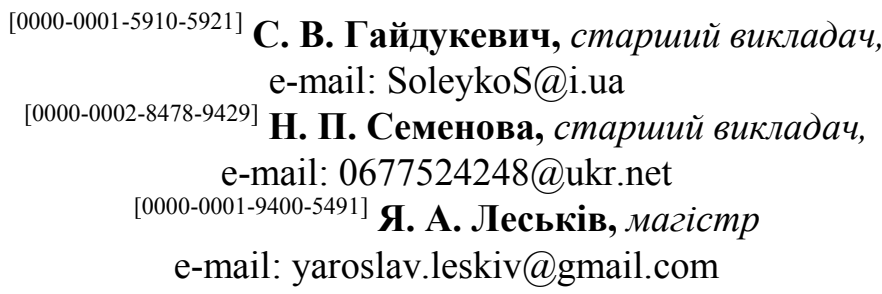

Відокремлений підрозділ Національного університету біоресурсів

і природокористування України «Бережанський агротехнічний інститут» вул. Академічна, 20, Тернопільська обл., м. Бережани, 47501, Україна

\title{
АВТОМАТИЗОВАНА СИСТЕМА КЕРУВАННЯ ЕЛЕКТРООБЛАДНАННЯМ У СПОРУДАХ ЗАКРИТОГО ГРУНТУ
}

Розроблено і виготовлено на базі мікроконтролера ATтеgа328 автоматичну систему керування, яка призначена для підвищення ефективності функціонування теплиці за рахунок моніторингу мікрокліматичних параметрів та обробки даних, щь дає змогу контролювати та своєчасно усувати відхилення параметрів, спричинені різноманітними збурюючими діями, від встановлених значень з метою створення сприятливих умов для проростання та життєдіяльності рослин.

В результаті досліджень встановлено, щзо запропонована розробка дає можливість підвищити надійність роботи електрообладнання під час експлуатащії, вдосконалити наявні механізми в результаті досягнення бажаного алгоритму, тобто наблизити процеси до стану оптимального балансу та зекономити витрату теплової енергї̈ на $10 \%$, тим самим зменшити енергоспоживання та підвищити продуктивність.

Ключові слова: автоматична система керування, мікроклімат, теплиия, мікропрочесор, функціонування.

Вступ. У спорудах захищеного грунту незалежно від змін зовнішнього середовища необхідно створювати сприятливі умови для вирощування рослин. Тому мікрокліматичні параметри повинні суворо контролюватися, знаходитися в обмежених зонах і безпосередньо враховуватися при автоматизації технологічних процесів.

Фактори, які потрібні для ефективного вирощування овочевих культур та інших рослин, вимагають автоматизації підтримки оптимальної температури і вологості повітря та грунту, забезпечення приміщень закритого грунту достатньою освітленістю та відповідною кількістю $\mathrm{CO}_{2}$. Тому проста автоматика, яка складається з реле часу і терморегулятора, на сьогоднішній день не задовольняе агропромислові вимоги, адже через великі втрати електроенергії сільськогосподарські підприємства стають нерентабельними.

3 появою різноманітних технічних засобів та інженерних систем у приміщеннях за- критого грунту підвищуються вимоги до якості підтримки мікроклімату. А це, в свою чергу, накладає високі вимоги до функціонування та технічного вдосконалення апаратного забезпечення систем керування [1], оскільки в застарілих системах автоматичного керування динамічні і статичні характеристики багатьох елементів і технологічних вузлів теплиці суттєво ускладнюють завдання якісного управління технологічними процесами [2], що зумовлює потребу у пошуку нових шляхів підвищення ефективності [3]. Водночас необхідно враховувати впливи зовнішніх і внутрішніх збурень, а це $є$ досить складною задачею.

На сьогоднішній день існує дуже багато різноманітних автоматичних систем, які застосовуються для автоматизації технологічних процесів, що допомагають вирощуванню сільськогосподарської продукції у закритому грунті. Всі вони мають свої переваги і недоліки. Однак одним із таких недоліків $є$ їх велика вартість, тому що автоматизація теплиці відно- 
ситься до дорогих i не завжди самоокупних заходів. I не всі господарства мають спроможність вкладати кошти в сучасні автоматичні системи. Тому питання побудови ефективних і недорогих систем автоматизації для теплиць [4] залишається невирішеним.

Аналіз останніх досліджень і публікацій. Значний внесок у розробку алгоритмів керування мікрокліматом захищеного грунту провели такі вчені, як акад. І. Ф. Бородін, акад. I. I. Мартиненко, акад. Л. Г. Прищеп, проф. В. П. Лисенко та ін.

У своїх працях науковці Т. О. Прокопенко, О. М. Свсеєнко, А. П. Ладанюк, Н. А. Заєць, О. Є. Білас та ін. вказують шляхи та методи використання інтелектуальних технологій, що пропонують суттєве спрощення систем автоматичного керування.

Крім того, багато пропозицій з використання автоматичних систем підтримання оптимального мікроклімату захищеного грунту можна знайти в Internet-мережі.

В проаналізованих працях [5-8] у режим мікроклімату переважно включаються чотири показники, такі як: температура повітря, вологість, кількість світла і рівень вуглекислого газу. Для керування цими параметрами пропонується обладнувати теплиці відповідними виконавчими системами: системою опалення, вентиляції, опромінення рослин, системою підживлення $\mathrm{CO}_{2}$. Запропоновані системи не тільки підтримують основні показники мікроклімату, але й дають змогу контролювати розширений набір показників, таких як температуру листа, вологість листа, розподіл температури повітря по вертикальному зрізу теплиці, швидкість руху повітряі т. д. [9].

Проте системи контролю i керування мікрокліматичними параметрами, які здатні функціонувати в режимі інформаційної невизначеності, майже не вивчені, а ті, що запропоновані, мають дуже велику вартість. Тому розробка і виготовлення доступної та інтелектуальної системи має велике значення в тепличному господарстві. І на сьогоднішній день, в умовах розвалу, економічної кризи і підвищення цін, це $є$ найактуальнішою темою, що істотно зменшує ризик інвестицій у сучасне тепличне господарство.

Мета дослідження - підвищення ефективності функціонування теплиці за рахунок розробки автоматичної системи керування та автоматизації електрообладнання для підтримання мікрокліматичних параметрів у приміщеннях закритого грунту.

Виклад основного матеріалу. Оскільки мікроклімат у теплиці залежить від зовнішніх (вологість повітря, зовнішня температура, сила вітру, сонячне освітлення), експлуатаційних (маса повітря, маса грунту) і конструкторських факторів впливу [10], характеризується незадовільною динамікою і нестабільністю параметрів [11], то на етапі проектування системи досить складно вибрати єдиний критерій керування [12]. Враховуючи всі ці збурюючі фактори, було поставлено завдання охопити всі етапи інтеграції процесів теплиці i, таким чином, дати можливість малозабезпеченим тепличним господарствам реалізувати інноваційні проекти [13], тим самим зменшити витрати на виробництво сільськогосподарської продукції. Враховуючи складність процесу оптимізації мікроклімату [14], для реалізації мети було знайдено комплексний підхід, який дає можливість одночасно моніторити всі показники мікроклімату приміщень закритого грунту, адже продуктивність залежить від збалансованості всіх процесів. Таким чином, у лабораторії «Електротехнології» було розроблено і виготовлено систему автоматичного керування технологічними процесами теплиці, яка складається 3 пристрою, програмного забезпечення і включає комп'ютерну техніку.

Робота і керування розробленим та виготовленим пристроєм автоматичного регулювання, що забезпечує необхідну точність параметрів мікроклімату захищеного грунту, базуються на застосуванні апаратно-обчислювальної платформи Arduino на основі мікроконтролера ATmega328 (datasheet). Мікроконтролер, що $\epsilon$ центром керування всіма процесами і базою для корегування параметрів, адаптований для використання $з$ макетної плати. В цьому випадку Arduino Nano припаяно до макетної плати, яка була замовлена та виготовлена на заводі JLCPCB за власним проектом студента Я.А. Леськіва, що був розроблений у форматі Gerber. сайти:

Було розроблено два індивідуальні

1) https://sites.google.com/view/controlboard, де подається конкретна інформація про сам пристрій, його роботу, монтаж, налаштування, програмне забезпечення $\mathrm{i}$ де 
можна придбати необхідні компоненти для виготовлення такого автоматичного пристрою керування;

2) https://photos.app.goo.gl/cyj2Shkusbf QeBReA, де представлено фотографії і відео 3 монтажу розробленого пристрою.

Цей пристрій дає можливість провести автоматизацію обладнання теплиці, а також піддавати оптимізації інші виробничі приміщення, де необхідно створювати оптимальний мікроклімат, витрачаючи мінімальні капіталовкладення, оскільки він зібраний 3 недорогих китайських компонентів, які легко можна придбати в інтернет-магазинах.

Принципову електричну схему зображено на рисунку 1.

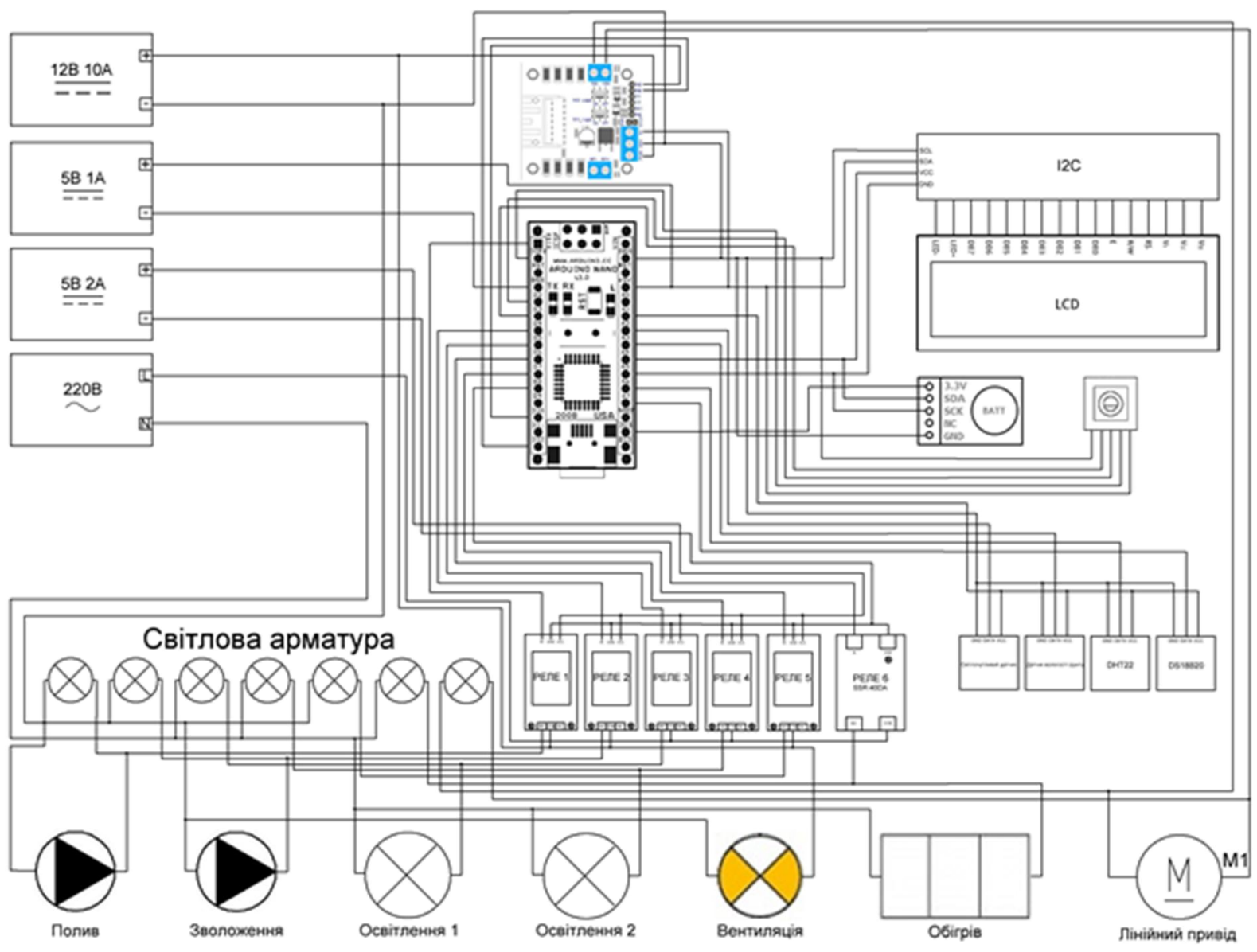

Рисунок 1 - Принципова електрична схема

У цьому пристрої використовується алгоритм зворотного зв'язку. Тобто вся інформація про об'єкт керування одержується датчиками і передається на виконавчі механізми.

Пристрій складається 3:

- корпуса, в якому монтуються всі компоненти;

- сигнальної арматури типу AD16DS LED (рисунок 2, в), що призначена для індикації роботи каналів (1 - помпа для системи поливу грунту; 2 - помпа для системи тума- ноутворення; 3 - система освітлення; 4 - система доосвічування (фітолампи); 5 - система вентилювання; 6 - система обігріву; 7 - лінійний актуатор для закривання i відкривання фрамуги 3 кінцевими вимикачами для обмеження руху і з роботою по тайм-ауту);

- повнофункціонального мініатюрного пристрою Arduino Nano 3 мікроконтролером ATmega 328p, що має 10 каналів, до яких підключено 7 реле, 2 модельні сервоприводи та 1 лінійний привід. 


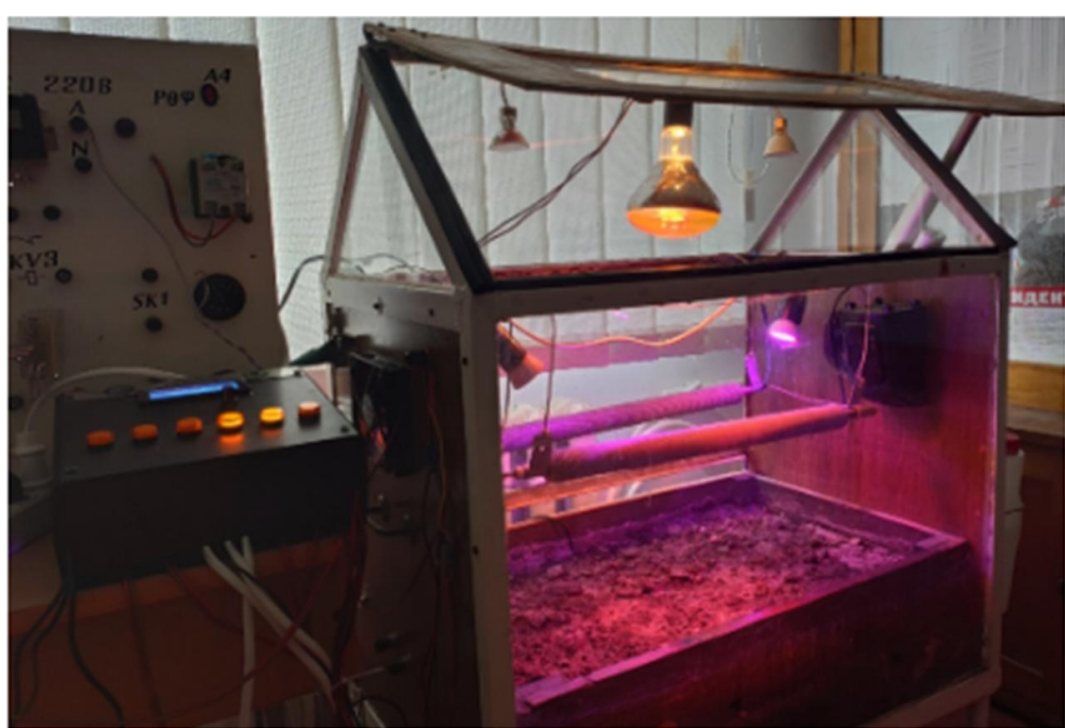

a)

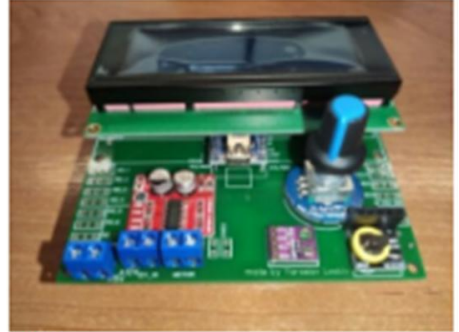

б)

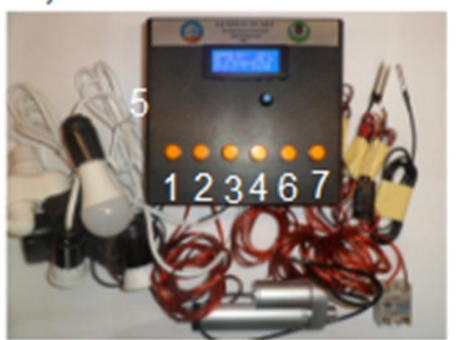

B)

Рисунок 2 - Загальний вигляд розробленого і виготовленого пристрою

Кожен із цих каналів має індивідуальне налаштування і може працювати по таймеру або за допомогою відповідних датчиків. Можна настроювати 4-6 режимів роботи, використовуючи три різні таймери або відповідні датчики:

- макетна плата (рисунок 2, б);

- енкодер, що є органом керування, за допомогою якого виконуються всі налаштування;

- дисплей (LCD 2004, 20 стовпців, 4 рядки), який відображає всю поточну інформацію;

- модуль реального часу RTC DS3231 3 автономним живленням;

- модуль драйвера, що здійснює керування двома колекторними двигунами, побудований на мікросхемі TB6612FNG;

- комбінований датчик температури і вологості повітря DHT21 / AM2301;

- цифровий датчик вологості грунту, який побудований на основі мікросхеми LM393;

- датчик температури грунту DS18B20;

- датчик освітлення 3 пороговим компаратором LM393;

- 5 реле типу JQC-3FF-S-Z на 12 В i 1 твердотільне реле типу SSR-40D;

- блок живлення логіки контролера на $5 \mathrm{~B}, 1 \mathrm{~A}$;

- блок живлення сервоприводу, реле i датчиків на 5 В, 2 A;

- блок живлення вентилятора, лінійного приводу на 12 В, 3 А.
Виконавчі механізми:

- помпа системи поливу;

- помпа системи туманоутворення;

- припливний і витяжний вентилятори;

- освітлювальна установка;

- установка для створення різного спектра освітлення (фітолампи);

- електрокалорифер;

- актуатор для відкривання і закривання фрамуги.

Запропонований багатофункціональний універсальний пристрій дає змогу виконувати наступні функції (рисунок 3):

- Зберігати всі налаштування в незалежній пам'яті. Тобто при перезавантаженні налаштування не скидаються.

- За допомогою системного таймера (модуль реального часу) створювати відлік локального часу, який зберігається тривалий час при відключенні основного живлення, використовуючи резервне живлення (батарейка CR2032). Це необхідно для відстежування параметрів керування системою та визначення часу доби.

- За датчиком температури і вологості або таймером виконувати провітрювання приміщення.

Вентиляція повітря стабілізує параметри мікроклімату та нормалізує його по вуглекислому газу. Для вентиляції приміщення використовуються припливний i витяжний вентилятори. Припливний вентилятор розташовується у верхній частині стіни для того, щоб у зимовий період часу не створювати про- 
тягів. Витяжний вентилятор створює систему рециркуляції повітря і знижує вологість. Для кожного виду рослин необхідно підтримувати відповідну вологість, тому що при перевищенні температурі і зниженні вологості нижче нормуючих значень ріст рослин призупиняється, а перевищення норм обох показників призводить до захворювання рослин. Вентилювання повітря в приміщенні закритого грунту створюється ще за допомогою фрамуг, які знаходяться в покрівлі. Відкривання і закривання фрамуг здійснюється за допомогою актуатора. Актуатори можна ще використовувати 3 датчиком, який визначає напрям вітру, щоб не зашкодити рослинам, але нині датчик вітру в нас не передбачено. Робота фрамуг використовується переважно для регулювання температури і вологості приміщення в літній період часу.
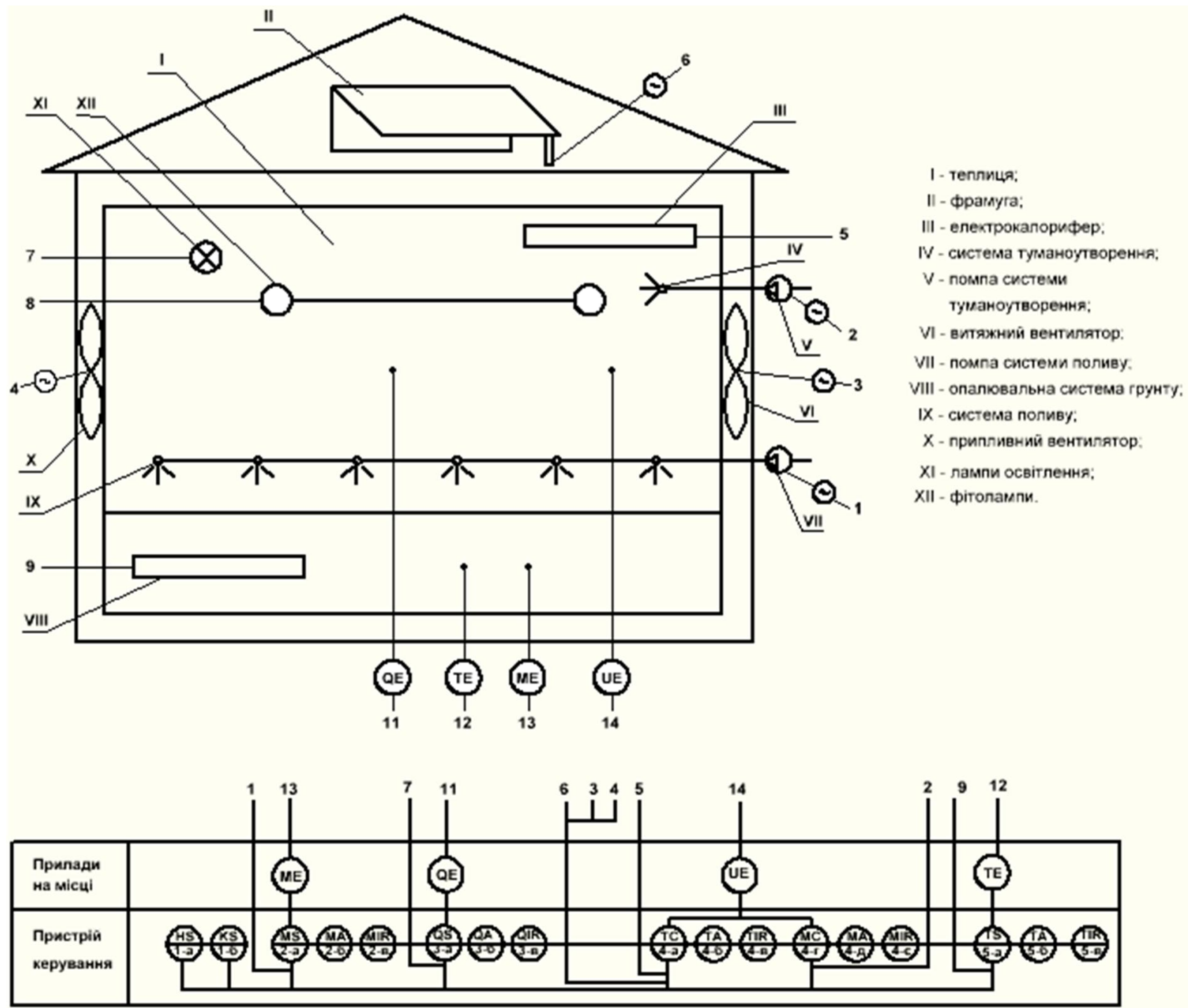

Рисунок 3 - Функціонально-технологічна схема

- Регулювати температуру повітря та грунту. Регулювання температури повітря і грунту здійснюється за допомогою датчиків, які контролюють температуру в приміщенні та грунту. Створювати оптимальну температуру в приміщенні закритого грунту можна за допомогою різних установок, наприклад таких, як теплогенератори, водяні калорифери, водяне опалення, електрокалорифери та ін.
Для генерування тепла в певний момент вибрано електрокалорифер. Оператор на дисплеї у вигляді графіків одержує інформацію про покази датчиків протягом заданого періоду. Діапазон температури повітря можна регулювати в широких межах залежно від виду вирощуваної культури і призначення. Обігрів грунту виконується стальним оцинкованим дротом, що прокладений під шаром грунту. 
Можна ще використовувати проводи ПОСХВ, ПОСХВТ або ПОСХП.

- Створювати полив грунту. Полив грунту контролюється за допомогою датчика вологості, який знаходиться безпосередньо в грунті, де ростуть рослини. Полив виконується системою зрошення - повільний, рівномірний, за принципом дощування, що сприяе зростанню рослин. Для підживлення рослин можна розробляти живильні розчини і ними поливати рослини.
- Зволожувати повітря. Для контролювання вологості й одночасно зниження температури повітря використовується система туманоутворення. Ввімкнення установки для створення водяного туману здійснюється за допомогою комбінованого датчика, що вимірює температуру і вологість у приміщенні.

На дисплеї відображаються графіки температури, вологості повітря і показники з аналогових датчиків за останню добу та оптимізований висновок (рисунок 4).
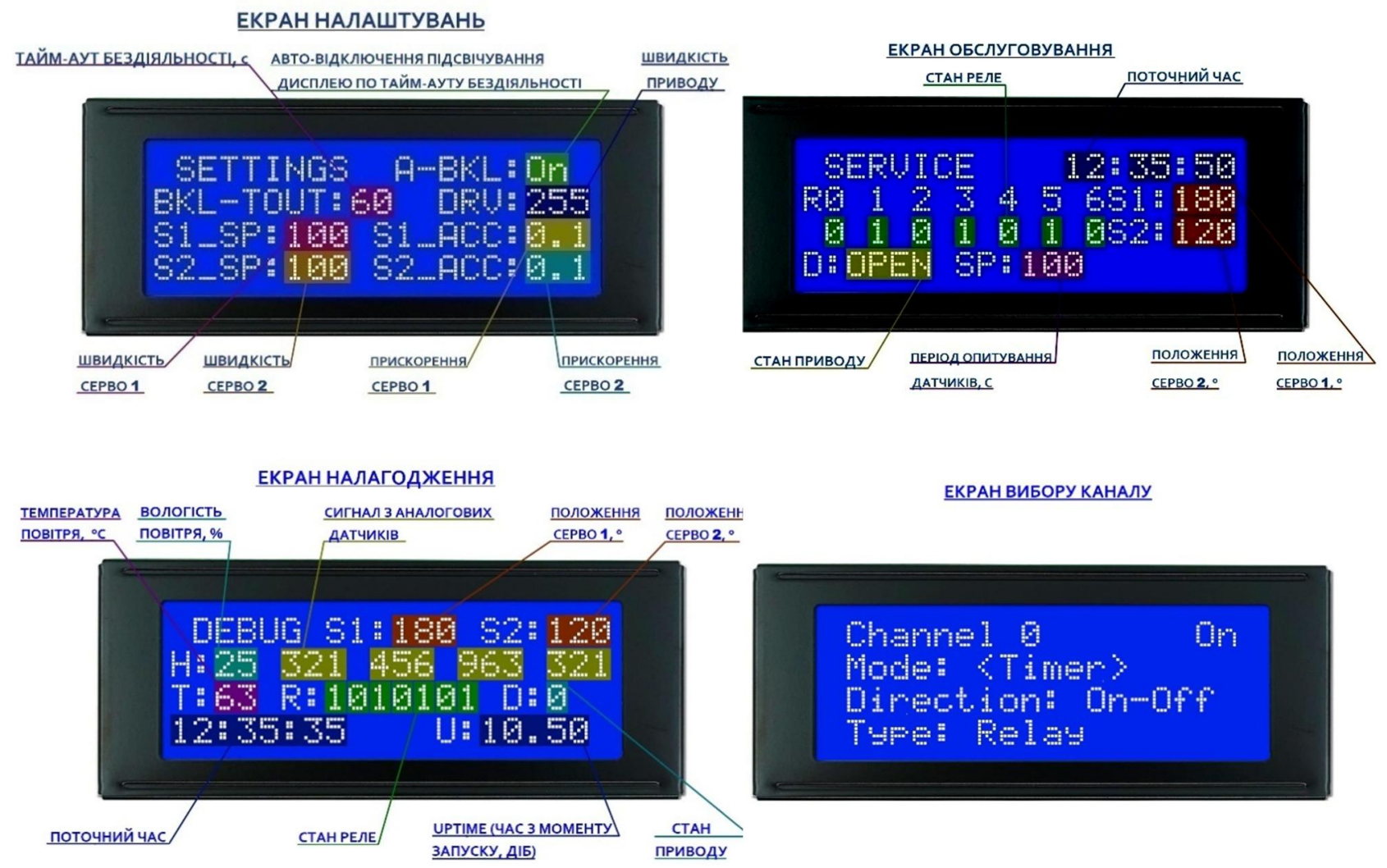

ЕКРАН ВИБОРУ КАНАЛУ

ЕКРАН НАЛАШТУВАННЯ РЕЖИМУ

ГPAФIK

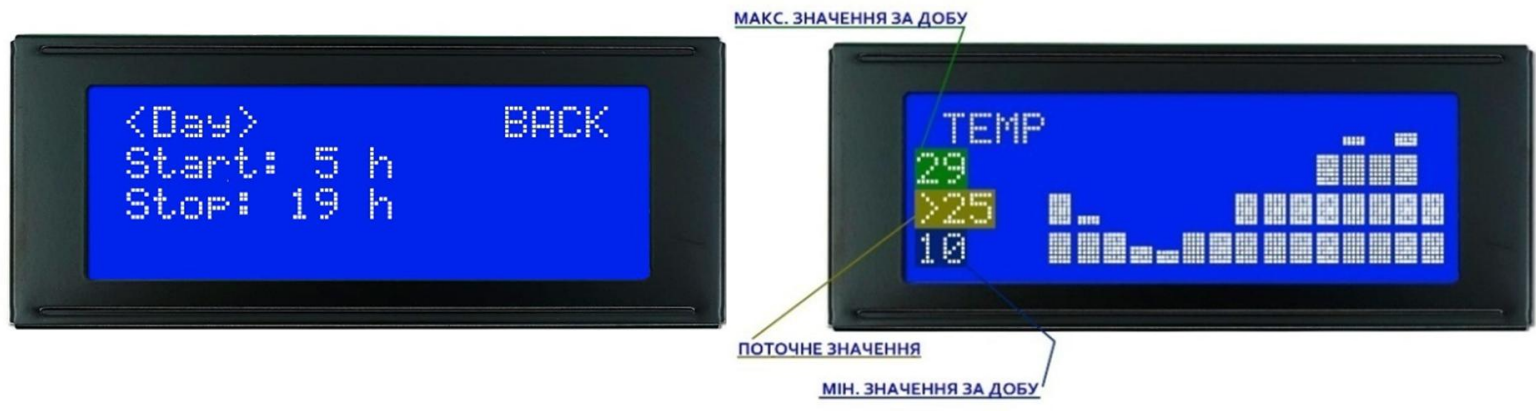

SETTINGS - установки; SERVICE - сервісний режим; R - реле; DEBUG - налагодження;

Channel 0 - Channel 6 - канали реле 0-6; Mode - режим, клік для переходу в налаштування режиму;

Direction - напрям роботи; Type - тип каналу реле; Relay - peле; Valve - клапан;

Day - добовий таймер; BACK - назад; Start - час початку роботи; Stop - час закінчення роботи;

TEMP - покази температури

\section{Рисунок 4 - Розшифровка написів на дисплеї}


- Створювати штучне освітлення. Освітлення $є$ основним і вирішальним фактором перебігу біологічних процесів у рослин, особливо в зимовий період часу. Якщо рослини будуть отримувати світло менше 10 годин на добу, уповільниться їх ріст, що є неприйнятним, особливо для вирощування розсади [15]. За рахунок штучного освітлення, яке імітує природні умови, забезпечується фотосинтез рослин, який приводить до прискорення обміну речовин у рослинах за умови, що система кондиціонування підтримує оптимальні значення температури й вологості повітря і грунту. При недостатній нормі освітленості рослини гинуть. Керування освітленням виконується 3 прив'язкою до часу доби. Тобто за допомогою відповідних настроювань можна вибрати необхідну тривалість дня, провести вибір температури для денного і нічного режимів роботи.

- Створювати освітлення різного світлового спектра. Для підвищення ефективності росту рослин використовуються фітолампи. 3 попередніх досліджень було доведено, що для кращого проходження фотосинтезу рослини потребують світла 3 певним спектральним складом.

Контроль i керування мікрокліматом приміщення можна виконувати як за таймером, так і за мікрокліматичними показниками. Тобто режими всіх перелічених функцій можна налаштовувати на таймер або на датчики, що контролюють мікрокліматичні параметри. Добавляючи різні датчики (звуку, ІЧ випромінювання, рівня води й ін.), можна ускладнювати систему, яка може спрацьовувати від інших факторів.

Сервісне меню дає змогу виконувати керування кожним каналом вручну.

Велика перевага пристрою полягає в тому, що датчики не перебувають постійно під напругою, напруга подається тільки під час опитування, що дає можливість продовжити термін їх роботи (напруга подається за 50 мс до опитування і вимикається через 50 мс після опитування).

Робота сервоприводу виконується плавно, без ривків і незапланованих рухів при старті системи, тобто плавний розгін і гальмування $з$ обмеженням максимальної швидкості за рахунок роботи сервоприводу з бібліотекою ServoSmooth.

Мікроконтролер пристрою Arduino Nano може живитися через кабель Mini-B
USB від зовнішнього джерела живлення зі стабілізованою напругою 5 В (через вивід 27) або з нестабілізованою напругою 6-20 В (через вивід 30). Мікросхема FTDI FT232RL дає змогу ArduinoNano підключатися до персонального комп'ютера і за допомогою спеціальної програми зчитувати прості текстові дані. Використовуючи бібліотеку SoftwareSerial, створюється послідовний зв'язок з будь-яким виводом мікроконтролера, а бібліотека Wire дає можливість спростити роботу 3 шиною $\mathrm{I} 2 \mathrm{C}$, що реалізує підтримку послідовних інтерфейсів. В мікроконтролер можна завантажувати нові програми без використання зовнішнього програматора за оригінальним протоколом SNR500. Для того щоб перед завантаженням програми не натискати кнопку скидання, один iз виходів мікросхеми FTDI FT232RL, що бере участь у керуванні потоком даних (DTR), 3'єднаний з виходом RESET мікроконтролера через конденсатор номіналом 100 нф. Це приводить до того, що, коли з'явиться нуль на лінії DTR, то вихід RESET переходить на низький рівень на час, який достатній для перезавантаження мікроконтролера, оскільки процес прошивки синхронізований зі спадом сигналу на лінії DTR. Ця операція використовується для того, щоб прошивати мікроконтролер одним натисненням кнопки в середовищі програмування Arduino, що дає можливість зменшити час завантаження. Для настроювання і відстежування всіх процесів по часу використано мінімодуль часу DS3231 з резервним живленням.

Розроблений i виготовлений пристрій автоматичного керування мікрокліматом теплиці було змонтовано в лабораторії «Електротехнології» на макеті теплиці (рисунок 2, а), де проводилися відповідні дослідження 3 насінням томатів, що проходили передпосівну обробку високою напругою. В результаті цього насіння томатів обробляли високою напругою і висівали в двох ідентичних теплицях. Для проростання насіння в обох теплицях створювали відповідний мікроклімат різними методами, а саме:

- 1 теплиця - керування автоматичною системою на базі мікропроцесора;

- 2 теплиця - керування ПІДрегуляторами.

Протягом визначеного часу проводилися спостереження за розвитком рослин, що проростали в теплиці, в якій мікрокліматичні параметри контролювалися розробленою ав- 
томатичною системою, і одночасно за рослинами, що проростали в теплиці, в якій параметри мікроклімату контролювалися ПІДрегуляторами.

В результаті спостережень було проаналізовано особливості технологічних процесів двох теплиць $з$ різними системами керування.

Протягом проведення досліджень розроблена система забезпечувала безперебійну роботу теплиці та з заданою точністю і чіткістю керувала технологічними процесами по забезпеченню оптимального мікроклімату, що приводило до швидшого проростання насіння і кращого розвитку рослин, адже суворе дотримання основних параметрів мікроклімату це запорука високої врожайності і стійкості рослин до захворювання [12].

Характеристики роботи пристрою показали, що в нього є великий потенціал, а саме, те, що він виконує постійний контроль за всіма показниками одночасно за рахунок датчиків, які передають інформацію на керуючий пристрій, яка потім поступає на блок обробки, після чого видаються сигнали на відповідні виконавчі механізми. Крім того, пристрій має функціональні можливості, що дає змогу вибирати метод керування залежно від виду рослин і фази росту, тобто система може працювати за строго заданою програмою або за часом, який встановлюється залежно від дня в місяці, години в дні. Інтеграція всіх функцій в одній системі створює нові можливості керування, результатом чого є підвищення ефективності оптимізації якості регулювання мікроклімату за рахунок логічного керування, що надає пристрою додаткові переваги. Тобто зменшується ризик виникнення помилок, на відміну від ручного керування декількома незалежними системами. Немаловажним є те, що розроблений пристрій замінює декілька окремих приладів:

- 2 регулятори температури повітря для імітації дня і ночі;

- регулятор вологості повітря;

- регулятор температури грунту;

- регулятор вологості грунту;

- реле часу;

- електромагнітний пускач освітлювальної установки;

- електромагнітний пускач вентиляційної установки та ін.

На відміну від розробленої автоматичної системи, установка на ПІД-регуляторах має наступні недоліки:

- відсутня можливість відстежування і контролю за всіма параметрами одночасно;

- технологічні вимоги забезпечуються із суттєвими відхиленнями від заданих значень, що знижує швидкість проростання насіння та якість продукції;

- відсутня можливість плавного регулювання мікрокліматичних параметрів, що призводить до більшого використання електроенергії (рисунок 5);

- значні енергетичні та теплові втрати, що знижують собівартість продукції (рисунок 6);

- велика кількість електрообладнання, що призводить до зменшення ймовірності безвідмовної роботи і, відповідно, до меншої надійності при експлуатації;

- всі пристрої великогабаритні, що займають багато місця.
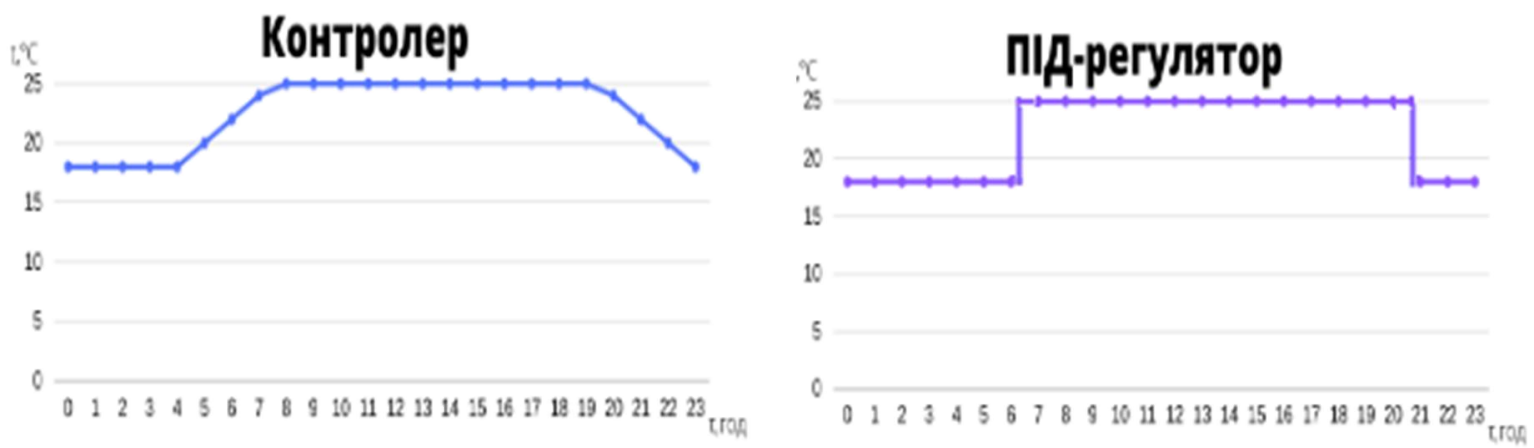

Рисунок 5 - Обігрів приміщення закритого грунту з імітацісю дня і ночі 


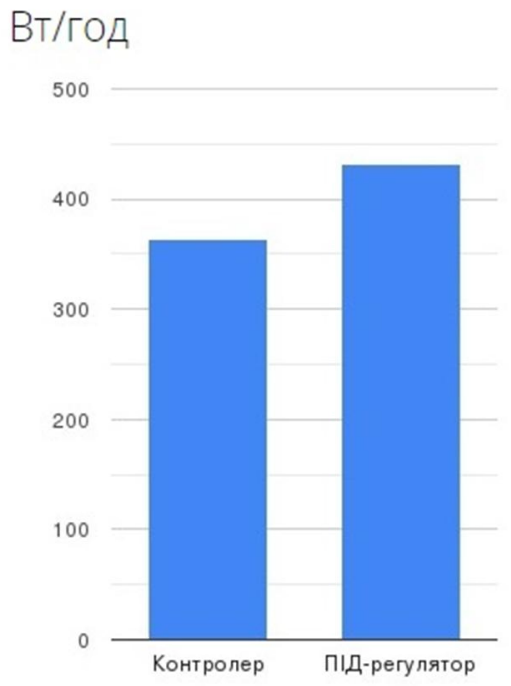

a)

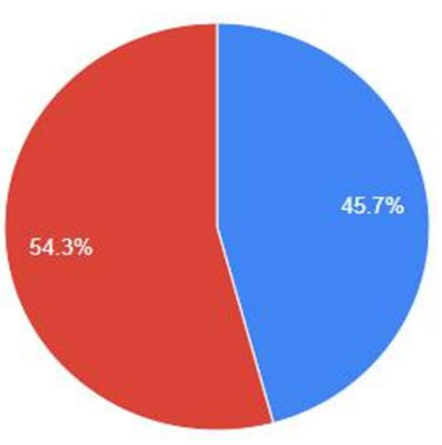

Контролер

ПІД-регулятор

Рисунок 6 - Витрати електроенергії на освітлення при функціонуванні теплиці за добу

Розроблена автоматична система порівняно 3 системами, що пропонують відомі компанії «OBEH», «ICP DAS», «EKF», науково-виробнича фірма «ФИТО» та ін., відповідно в 10 і більше разів дешевша. Враховуючи вартість усіх компонентів, додаткових пристроїв, блоків живлення та їх постачання, вартість розробленої і виготовленої установки становить 2530 грн. Це порівняно дуже дешево, що під силу найбільш малозабезпеченим тепличним господарствам.

Висновки i пропозиції. Розроблена і виготовлена система керування та її програмне забезпечення можуть бути використані для керування мікрокліматичними параметрами в теплицях для вирощування різних сільськогосподарських культур, оскільки є можливість регулювання вхідних параметрів у широких межах.

Система працює 3 досить високою точністю, що дає можливість підвищити ефективність роботи теплиці, а також знизити витрати на паливно-енергетичні ресурси.

Алгоритм роботи електрообладнання теплиці для підтримання мікрокліматичних параметрів дає змогу знизити споживання теплової енергії на $10 \%$ за рахунок того, що всі параметри тісно пов'язані між собою, тому передбачено можливість одночасного їх контролювання та керування, налаштування обмеження зон параметрів мікроклімату та створення імітації дня і ночі, причому показники температури і вологості відповідно наближаються до реального середовища.

Чіткість роботи електрообладнання за рахунок розробленої автоматичної системи не залежить від кліматичних умов та інших факторів, що дає можливість підвищити ефективність виконуваних технологічних процесів, в результаті яких покращується якість продукції та зменшується термін іiї вирощування, що забезпечує ефективне круглорічне функціонування високорентабельних тепличних господарств.

Виготовлену автоматичну систему можна використовувати не тільки для різного типу і призначення теплиць, але й в інкубаторах та для створення мікроклімату в приміщеннях іншого типу. Тобто ця система $є$ багатофункціональною. Тому перед нами стоїть задача удосконалення системи і надання можливості відстежування параметрів мікроклімату та отримання повідомлень про їх значення за допомогою мобільного зв'язку.

\section{Список використаних джерел}

[1] Д. А. Смірнов, та О. В. Матус, "Автоматизація процесу керування температурновологісним режимом у фермерській теплиці", Вісник навчально-наукового інституту автоматики, кібернетики та 
обчислювальної техніки НУВГП: зб. наук. пр., вип. 6, с. 85-93, Рівне: НУВГП, 2019.

[2] С. М. Москвіна, та О. Ю. Гнатюк, "Метод управління тепловологісним режимом у промисловій теплиці", на XIII Міжнар. конф. Контроль і управління в складних системах (КУСС-2016), Вінниця: ВНТУ, 2016, c. 101-103.

[3] О.В. Шульц, "Дослідження та розробка інформаційно-управляючої scada-системи процесом опалення у теплиці", на 70-ц̌ наук.-практ. конф. студентів "Енергозабезпечення, електротехнології, електротехніка та інтелектуальні управляючі системи в АПК", Київ: НУБіП України, 2016, c. 82.

[4] В. П. Лисенко, І. М. Болбот, та I. I. Чернов, "Економічне обгрунтування впровадження роботехнічних систем у тепличні господарства", Науковий вісник Наиіонального університету біоресурсів і природокористування Украӥни. Серія: Техніка та енергетика АПК, вип. 174 (2), с. 5359, 2012.

[5] Т. О. Прокопенко, "Інтелектуальна система керування температурно-вологісним режимом теплиці", Науковий вісник Наиіонального університету біоресурсів і природокористування України. Серія: Техніка та енергетика АПК, вип. 209, ч. 1, с. 140-147, 2015.

[6] Л. Г. Прищеп, Эффективная электрификаиия защищенного грунта. Москва: Колос, 1980.

[7] О. Б. Бондарева, Устройство теплии $u$ парников: Конструкиии устройств обогрева, вентиляции и полива в индивидуальных теплицах. Москва: АСТ, 2006.

[8] А. Ладанюк, Н. Заєць, та Н. Власенко, Сучасні технології конструювання систем автоматизачії складних об'єктів. Київ: Ліра-К, 2016.

[9] Профессиональное тепличное оборудование. Москва. [Электронный ресурс]. Режим доступа: http://www.fito-system.ru/.

[10] I. Г. Цмоць, та Т. В. Теслюк, "Структура та моделі роботи системи управління мікрокліматом мінітеплиці", Вісник Національного університету "Львівська політехніка". Комп'ютерні науки та інформаиійні технології, № 843, с. 228-237, 2016.

[11] В. О. Сацик, та Д. П. Карпук, "Апаратне забезпечення автоматизованого регулювання мікроклімату теплиці", Наукові но- татки: міжвуз. зб., вип. 40, с. 245-250, Луцьк, 2013.

[12] Л. Г. Віхрова, В. М. Каліч, та Т. О. Прокопенко, "Адаптивна автоматизована система збору та контролю основних параметрів мікроклімату в теплиці", Техніка в сільськогосподарському виробництві, галузеве машинобудування, автоматизація: зб. наук. пр., вип. 29, с. 168-172, Кіровоград: КНТУ, 2016.

[13] Н. Ю. Кривицька, В. Є. Командровська, та В.В.Андрущенко, "Інтеграційні процеси підприємств України: визначення, види та напрями", Економіка та управління підприємствами, вип. 24, с. 131134, 2017.

[14] В. Т. Діордієв, А. О. Кашкарьов, та О. О. Діордієв, "Автоматизована система моніторингу та керування мікрокліматом у теплиці", Науковий вісник ТДАТУ: матеріали наук.-техн. конф. студентів та магістрантів, вип. 8, т. 2, Мелітополь, 2018.

[15] О. М. Євсеєнко, "Розробка апаратнопрограмної системи керування мікрокліматом теплиці", Технічна інженерія, № 1 (85), c. 104-109, 2020.

\section{References}

[1] D. A. Smirnov, and O. V. Matus, "Automation of the process of temperature and humidity conditions control in the greenhouse", Visnyk navchalno-naukovoho instytutu avtomatyky, kibernetyky ta obchysliuvalnoi tekhniky NUVHP: coll. of sci. works, iss. 6, pp. 85-93, Rivne: NUWEE, 2019 [in Ukrainian].

[2] S. M. Moskvina, and O. Yu. Hnatiuk, "Method of heat and moisture regime control in an industrial greenhouse", in XIII Int. Conf. Measurement and control in complex systems (MCCS - 2016), Vinnytsia: VNTU, 2016, pp. 101-103 [in Ukrainian].

[3] O. V. Schultz, "Research and development of information control scada-system for the heating process in a greenhouse", in 70th Sci.-Pract. Students' Conf. Energy Supply, Electrical Technologies, Electrical Engineering and Intelligent Control Systems in Agriculture, Kyiv: NUBiP Ukrainy, 2016, p. 82 [in Ukrainian].

[4] V. P. Lysenko, I. M. Bolbot, and I. I. Chernov, "Economic substantiation of introduction of robotic systems in greenhouses", 
Naukovyi visnyk Natsionalnoho universytetu bioresursiv i pryrodokorystuvannia Ukrainy. Seriia: Tekhnika ta enerhetyka APK, iss. 174 (2), pp. 53-59, 2012 [in Ukrainian].

[5] T. O. Prokopenko, "Intelligent system for temperature and humidity control of a greenhouse", Naukovyi visnyk Natsionalnoho universytetu bioresursiv $i$ pryrodokorystuvannia Ukrainy. Seriia: Tekhnika ta enerhetyka APK, iss. 209, part 1, pp. 140147, 2015 [in Ukrainian].

[6] L. G. Prischep, Effective electrification of protected soil. Moscow: Kolos, 1980 [in Russian].

[7] O. B. Bondareva, The device of greenhouses and hotbeds: Designs of devices of heating, ventilation and watering in individual greenhouses. Moscow: AST, 2006 [in Russian].

[8] A. Ladanyuk, N. Zayets, and N. Vlasenko, Modern technologies for designing automation systems for complex objects. Kyiv: Lira-K, 2016 [in Ukrainian].

[9] Professional greenhouse equipment. Moscow. [Online]. Available: http://www.fitosystem.ru/. [in Russian].

[10] I. G. Tsmots, and T. V. Teslyuk, "Structure and models of operation of the minigreenhouse microclimate control system", Visnyk Natsionalnoho universytetu "Lvivska politekhnika". Kompiuterni nauky ta infor- matsiini tekhnolohii, no. 843, pp. 228-237, 2016 [in Ukrainian].

[11] V. O. Satsik, and D. P. Karpuk, "Hardware for automated regulation of greenhouse microclimate", Naukovi notatky: interuniversity coll., iss. 40, pp. 245-250, Lutsk, 2013 [in Ukrainian].

[12] L. G. Vikhrova, V. M. Kalich, and T. O. Prokopenko, "Adaptive automated system for collection and control of basic parameters of microclimate in a hothouse", Tekhnika $v$ silskohospodarskomu vyrobnytstvi, haluzeve mashynobuduvannia, avtomatyzatsi$i a$ : coll. of sci. works, iss. 29, pp. 168-172, Kirovohrad, 2016 [in Ukrainian].

[13] N. Yu. Kryvytska, V. Ye. Komandrovska, and V. V. Andrushchenko, "Integrated processes of enterprises of Ukraine: definitions, types and directions", Ekonomika ta upravlinnia pidpryiemstvamy, iss. 24, 2017 [in Ukrainian].

[14] V. T. Diordiev, A. O. Kashkarov, and O. O. Diordiev, "Automated monitoring and control system for greenhouse microclimate", Naukovyi visnyk TDATU: Proc. of the sci. and tech. conf. of students and undergraduates, iss. 8, vol. 2, Melitopol, 2018 [in Ukrainian].

[15] O. M. Evseenko, "Development of hardware and software system for greenhouse microclimate control", Tekhnichna inzheneriia, no. 1 (85), pp. 104-109, 2020 [in Ukrainian].

S. V. Gaydukevich, senior lecturer, e-mail: SoleykoS@i.ua

N. P. Semenova, senior lecturer, e-mail:0677524248@ukr.net

Ya. A. Leskiv, student, master e-mail: yaroslav.leskiv@gmail.com

Separated subdivision of the National University of Bioresources and Natural Use of Ukraine

"Berezhansky agrotechnical institute",

Akademichna st., 20, Ternopil region, Berezhany, 47501, Ukraine

\section{AUTOMATED ELECTRICAL EQUIPMENT CONTROL SYSTEM IN INDOOR GROUND STRUCTURES}

Today, greenhouses with outdated technology suffer great losses. To increase the efficiency of greenhouses, it is necessary to rapidly automate the electrical equipment of technological processes to maintain microclimatic parameters in order to create favorable conditions for germination and plant life.

Modern automated systems offered by the market are expensive, so for small greenhouses they have a very long payback period and low profitability. 
Due to the economic crisis and the inability of many greenhouses to re-equip production processes using state-of-the-art automatic control systems based on an integrated approach, which includes modern electrical equipment, software, the development of intelligent, multifunctional automatic microclimate control system based on ATmega 328 microcontroller, that allows to increase the efficiency of the greenhouse by monitoring microclimatic parameters and data processing and to control and timely eliminate deviations of parameters caused by various disturbances from the set values in order to create favorable conditions for plant germination and viability is proposed.

The basic electric scheme of control of a greenhouse microclimate system the principle of work of which is based on automatic control by means of the programming block is developed. The selection of sensors for monitoring the parameters of the microclimate and intermediate relays for the operation of actuators is made.

As a result of research it is established that the proposed development allows to increase the reliability of electrical equipment during operation, improve existing mechanisms as a result of achieving the desired algorithm, that is, to bring processes closer to optimal balance and save heat consumption by $10 \%$, thereby reducing energy consumption and increasing productivity.

The proposed system can be used not only to control the microclimate parameters of different types of greenhouses, but also to control the microclimate of incubators and various production apartments.

Keywords: automatic control system, microclimate, greenhouse, microprocessor, functioning.

Стаття надійшла 12.02.2021

Прийнято 11.03.2021 